\title{
PENGARUH HAFALAN AL-QUR'AN DAN INTENSITAS SHOLAT TAHAJUD TERHADAP PRESTASI BELAJAR MATA PELAJARAN QUR'AN-HADIS
}

\author{
Sayidatun Wihardina Awaliah, Moh. Abdul Kholiq Hasan, Ari Anshori \\ Redaktur Majalah Syamil Pondok Pesantren Islam Al-Mukmin Ngruki Sukoharjo \\ E-Mail: swamaliah122@yahoo.co.id
}

\begin{abstract}
The aim of the compiling of the study was to find out and explain the academic matters, was to find out how big the effect of memorizing al-Qur'an and the intentity of tahajud prayer toward academic achievement of Qur'an Hadis either collectively or partially. The study was quantitative with education as its scope. Rather it used the combination of library and field research as its research place. The collecting data used questionnaire and documentation. The validation of the research instrument by analizing items was counted with correlation formula 'Product Moment', and the reliability was counted by formula Alpha Cronbach. The technique of analizing data to examine hypothesis was correlation analysis technique of Product Moment and technique double regression two predictors.

The result of the study showed that significance level 5\% was acquired by the value of $t$ count of either memorizing al-Qur'an or intentity of tahajud prayer was 0,182 and 0,579, whereas the value of $t$ table was 2,026. Since $t$ count $<t$ table, it can be inferred that neither memorizing al-Qur'an nor intentity of tahajud prayer has significant effect toward academic achievement of Qur'an Hadis. In addition, based on the result of the study, the test value of F count was 0,389 and based on the table, the value of F table was 3,245. Since F count $<F$ table, the conclusion was that there was no significant effect of memorizing al-Qur'an and intentity of tahajud prayer on academic achievement of Qur'an Hadis collectively. Based on the analizing, the researcher found the other factor that could influence students academic achievement was motivation, either motivation of memorizing al-Qur'an or tahajud prayer.
\end{abstract}

Keyword: memorizing al-Qur'an, intentity of tahajud prayer, academic achievement

Abstrak: Disusunnya penelitian ini bertujuan untuk mengetahui dan menjelaskan hal-hal yang terkait dengan problem akademik, yaitu:mengetahui seberapa besar pengaruh hafalan al-Qur'an dan intensitas salat tahajud baik secara bersama-sama atau parsial terhadap prestasi belajar Qur'an Hadis. Penelitian ini termasuk dalam penelitian kuantitatif dengan pendidikan sebagai ruang lingkup penelitiannya dan menggabungkan kepustakaan (library research) dan lapangan (field research) sebagai tempat penelitiannya.Metode pengambilan data menggunakan angket dan dokumentasi. Validitas instrument penelitian dilakukan dengan analisis butir hitung dengan rumus korelasi product moment. Reliabilitas instrument dihitung dengan menggunakan rumus Alpha Cronbach. Teknik analisis data yang dipakai untuk menguji hipotesis adalah teknik analisis korelasi Product moment dan teknik regresi ganda 2 prediktor.Hasil penelitian menunjukkan dengan taraf signifikan $5 \%$ diperoleh nilai thitung hafalan al-Qur'an dan intensitas salat tahajud secara berurutan sebesar 0,182 dan 0,579, sedangkan t tabel 2,026. Karena thitung < t tabel maka dapat disimpulkan bahwa baik hafalan al-Qur'an maupun intensitas salat tahajud tidak memiliki pengaruh yang signifikan terhadap prestasi belajar Qur'an Hadis. Kemudian berdasar hasil penelitian diperoleh nilai uji $F$ hitung sebesar 0,389 dan berdasar tabel diperoleh nilai $F$ Tabel sebesar 3,245. Karena F hitung $<F$ tabel maka dapat disimpulkan bahwa tidak terdapat pengaruh yang signifikan secara bersama sama antara hafalan al-Qur'an dan intensitas salat tahajud terhadap nilai mata pelajaran Qur'an Hadis. Berdasarkan analisis yang dilakukan, peneliti menemukan faktor lain yang bisa mempengaruhi prestasi belajar santriwati, yaitu motivasi. Baik motivasi menghafal al-Qur'an ataupun motivasi salat tahajud.

Kata Kunci: hafalan al-Qur'an, intensitas salat tahajud, dan prestasi belajar, 


\section{PENDAHULUAN}

Al-Qur'an adalah kitab suci umat Islam yang diturunkan oleh Allah Swt. sebagai pedoman hidup bagi seluruh umat manusia. Al-Qur'an merupakan satusatunya kitab suci yang dijamin kesucian dan kemurniannya selama-lamanya. Namun, secara operasional menjadi tugas dan kewajiban umat Islam untuk selalu menjaga dan memeliharanya, salah satunya adalah dengan menghafalkannya. Hal ini menunjukkan bahwa menghafal al-Qur'an merupakkan salah satu amal shaleh yang dianjurkan untuk mengerjakannya. Begitu pula dengan salat tahajud. Dalam salah satu hadis, Allah menjelaskan bahwa salat tahajud merupakan salat yang paling utama dilaksanakan setelah salat wajib. Hal ini menunjukkan banyak keutamaan dibalik salat tahajud. Salah satunya adalah dikabulkannya doa bagi siapa saja yang berdoa setelah melaksanakan salat tahajud.

Pondok Pesantren Islam Al-Mukmin dan Pondok Pesantren Modern Islam Assalaam merupakan pondok modern yang berupaya memberlakukan kurikulum yang komperehensif, yaitu dengan mengintegrasikan kurikulum pendidikan nasional dan kurikulum pesantren, yang bertujuan mencetak lulusan yang berhasil dalam aspek akademik maupun non akademik.

Salah satu upaya yang dilakukan oleh dua lembaga pendidikan tersebut untuk menghasilkan peserta didik yang berakhlak karimah adalah dimunculkannya program tahfihz. Semua santriwati kelompok tahfizh menginap dalam satu kamar atau santriwati yang mengikuti kelompok tahfizh memiliki kamar khusus untuk tinggal setelah kembali dari sekolah. ${ }^{1}$

Berdasarkan observasi awal yang penulis lakukan, ditemukan bahwa santriwati Pondok Pesantren Islam AlMukmin dan Pondok Pesantren Modern Islam Assalaam memiliki jad wal yang sangat padat, meskipun demikian, bagi santriwati menghafal al-Qur'an di pondok tidak lantas menelantarkan kegiatan-kegiatan mereka.

1 Wawancara dengan ustadzah penanggung jawab tahfizh Pondok Pesantren Islam Al-Mukmin dan Assalaam Sukoharjo pada tanggal 7 Agustus 2014
Bahkan, akan semakin cemerlang dan menjadi semakin mudah dari sebelumnya. Hal ini berlaku juga terhadap prestasi belajar mata pelajaran Qur'an Hadis. Tidak menutup kemungkinan, tingkat intensitas salat tahajud lebih banyak, dan perilaku yang lebih baik dibanding dengan santriwati yang tidak mengikuti kelompok tahfizh al-Qur'an. ${ }^{2}$

Sejauh pengetahuan peneliti, penelitian yang secara khusus membahas tentang pengaruh hafalan al-Qur'an dan intensitas salat tahajud terhadap prestasi belajar qur'an hadis belum ada yang mengkajinya. Selama ini, penelitian terdahulu yang telah dilakukan hanya meneliti satu variabel bebas dan satu variabel terikat saja atau dua variabel bebas hanya saja variabel pembanding atau variabel bebas dua berbeda dengan peneliti, seperti pengaruh hafalan al-Qur'an terhadap preatasi belajar atau pengaruh salat tahajud dengan ketenangan jiwa. Penelitian tersebut, antara lain: pertama, penelitian yang disusun Ferri Andika Rosadi dan Muhammad Munir pada tahun 2014 dengan judul "Pengaruh Kemampuan Menghafal Al-Qur'an dan Motivasi Belajar terhadap Prestasi Belajar Siswa Ekstrakurikuler Elektronika SMP Islam Terpadu Abu Bakar Yogyakarta". ${ }^{3}$ Penelitian ini menyingkap ada dan tidaknya pengaruh menghafal al-Qur'an dan motivasi belajar terhadap prestasi belajar Siswa Ekstrakurikuler Elektronika baik secara parsial ataupun bersma-sama. Melalui penelitian ini Ferri Andika Rosadi dan Muhammad Munir menyimpulkan, bahwa terdapat pengaruh positif secara bersama-sama, antara menghafal al-Qur'an dan motivasi belajar terhadap prestasi belajar Siswa Ekstrakurikuler Elektronika dengan sumbangan efektif sebesar 28 \%. Dan pengaruh positif secara parsial antara menghafal al-Qur'an terhadap prestasi belajar Siswa Ekstrakurikuler

2 Ibid.

3 Ferri Andika Rosadi dan Muhammad Munir, "Pengaruh Kemampuan Menghafal Al-Qur'an dan Motivasi Belajar terhadap Prestasi Belajar Siswa Ekstrakurikuler Elektronika SMP Islam Terpadu Abu Bakar Yogyakarta", dalam Jurnal Elektronik Pendidikan Teknik Elektronika. Edisi 3, Volume 3, Nomor 1, Januari-Februari 2014. (Yogyakarta: Fakultas Teknik Universitas Negeri Yogyakarta, 2014) 
Elektronika dan pengaruh positif motivasi belajar terhadap prestasi belajar siswa ekstrakurikuler elektronika dengan dengan sumbangan efektif secara berurutan 16\% dan $28 \%$. Perbedaan penelitian Ferri Andika Rosadi dan Muhammad Munir dengan peneliti terletak pada variabel bebas, yaitu kemampuan menghafal alQur'an dan motivasi belajar, variabel terikat prestasi belajar siswa ekstrakurikuler elektronika. Sedangkan penelitian yang dilakukan peneliti menggunakan variabel bebas hafalan al-Qur'an dan intensitas salat tahajud, dan variabel terikat prestasi belajar Qur'an Hadis.

Kedua, penelitian Nazia Nawaz dan Syeda Farhana Jahangir pada tahun 2015 yang berjudul "Effects of Memorizing Quran by Heart (Hifz) on Later Academic Achievement."." 4 Nazia Nawaz dan Syeda Farhana Jahangir membahas tentang pengaruh menghafal al-Qur'an dalam hubungannya dengan prestasi akademik dan kehidupan sosio-budaya para penghafal al-Qur'an (Huffazh). Teknik analisis menunjukkan pengaruh/dampak positif menghafal al-Qur'an terhadap pendidikan dan kehidupan sosio-budaya Huffazh secara keseluruhan. Hasil penelitian menunjukkan perbedaan pengaruh prestasi akademik sebelum menghafal $(5,58)$ dan sesudah menghafal $(8,17)$.

Ketiga, penelitian Maulida Nisful Laila tahun penelitian 2014 dengan judul “Korelasi antara Pelaksanaan Salat Tahajud dan Prestasi Belajar Aqidah Akhlak Siswa di MAN Denanyar Jombang"5. Penelitian ini bertujuan untuk mengetahui ada tidaknya korelasi antara pelaksanaan salat tahajud dan prestasi belajar Aqidah Akhlak siswi di MAN Denanyar Jombang tahun ajaran 2013/2014. Hasil analisa penelitian Maulida menunjukkan adanya korelasi atau hubungan. Hal ini dibuktikan dengan skor

4 Nazia Nawaz dan Syeda Farhana Jahangir, Effects of Memorizing Quran by Heart (Hifz) on Later Academic Achievement, (Amerika: American research institute for policy development, 2015), hlm. 58-64

5 Maulida Nisful Laila, "Korelasi Antara Pelaksanaan Shalat Tahajud dan Prestasi belajar Aqidah Akhlak Siswa di MAN Denanyar Jombang", Skripsi, (Surabaya: Universitas Islam Negeri Sunan Ampel, 2014). nilai $r_{\text {hitung }} 0,630$ dan $r_{\text {tabel }}$ dengan taraf signifikan $5 \%$ adalah 0,250 . Karena $r_{\text {hitung }}$ $>r_{\text {tabel }}$. Penelitian Maulida Nisful Laila menggunakan teknik analisis data korelasi product moment, sedangkan penelitian ini menggunakan dua teknis analisis, yaitu analisis korelasi product moment dan teknik regresi ganda 2 prediktor.

Penelitian ini akan membatasi masalahnya dalam dua variabel bebas dan sati vriabel terikat. Yakni hafalan alQur'an sebagai variabel bebas pertama dan intensitas salat tahajud sebagai variabel bebas dua, sedangkan variabel terikat peneliti menggunakan preatsi belajar Qur'an hadis. Oleh karena itu, penelitian ini akan menjawab pertanyaan-pertanyaan akademik sebagai berikut: Pertama, Apakah terdapat pengaruh yang signifikan secara bersama-sama antara hafalan al-Qur'an dan intensitas salat tahajud terhadap prestasi belajar mata pelajaran Qur'an Hadis pada santriwati kelas VIII MTs. Islam Ngruki dan MTs. PPMI Assalaam semester gasal tahun pelajaran 2014/2015?. Kedua dan ketiga, Apakah terdapat pengaruh yang signifikan secara parsial hafalan al-Qur'an terhadap prestasi belajar mata pelajaran Qur'an Hadis dan antara intensitas salat tahajud terhadap prestasi belajar mata pelajaran Qur'an Hadis pada santriwati kelas VIII MTs. Islam Ngruki dan MTs. PPMI Assalaam semester gasal tahun pelajaran 2014/2015?

Penelitian ini bertujuan untuk mengetahui dan menjelaskan hal-hal yang terkait dengan problem akademik sebagaimana dikemukakan dalam rumusan masalah penelitian, yaitu: pertama, mengetahui ada dan tidaknya pengaruh yang signifikan secara bersama-sama antara hafalan al-Qur'an dan intensitas salat tahajud terhadap prestasi belajar mata pelajaran Qur'an Hadis pada santriwati kelas VIII MTs. Islam Ngruki dan MTs. PPMI Assalaam semester gasal tahun pelajaran 2014/2015. Kedua dan ketiga, mengetahui ada dan tidaknya pengaruh yang signifikan secara parsial hafalan al-Qur'an terhadap prestasi belajar mata pelajaran Qur'an Hadis dan antara intensitas salat tahajud terhadap prestasi belajar mata pelajaran Qur'an 
Hadis pada santriwati kelas VIII MTs. Islam Ngruki dan MTs. PPMI Assalaam semester gasal tahun pelajaran 2014/2015.

\section{METODE PENELITIAN}

Penelitianinitermasuk dalam penelitian kuantitatif dengan pendidikan dan agama sebagai ruang lingkup penelitiannya. Kepustakaan (library research) dan lapangan (field research) sebagai tempat penelitiannya. Data yang didapat kemudian disajikan dengan statistik dan diskriptif dengan menggunakan pendekatan psikologis dan phenomenologis. Sumber data dalam penelitian ini diklasifikasikan ke dalam dua golongan, yaitu data primer dan data sekunder. Data-data dikumpulkan dengan menggunakan teknik observasi, interview, kuesioner, dokumentasi.

Peneliti mengggunakan diuji validitas an uji reliabilitas. Uji validitas datanya dilakukan menggunakan komputer dengan program Statistical Program for Social Science (SSPS) for Windows Versi 21 sebagai program analisis kesahihan butir. Parameter yang digunakan adalah dengan membandingkan hasil korelasi atau $r_{\text {hitung }}$ dengan $r_{\text {tabel }}$ atau menggunakan probabilitas. Pengambilan keputusan pada saat menguji kevalidan instrumen adalah jika $r_{\text {hitung }>r_{\text {tabel }}}$ maka instrumen dikatakan valid atau jika probabilitas $(\mathrm{sig})<0,05$, maka instrumen dapat dikatakan valid. Uji reliabilitas dilakukan dengan metode atau rumus Alpha Croncbach. Rumus ini menentukan konsistensi internal atau korelasi rata-rata semua item yang ada dalam instrumen untuk menguji realibilitas. Instrumen yang mempunyai reliabilitas apabila koefisien Alpha Cronbach lebih besar daripada nilai kritisnya.

\section{HASIL DAN PEMBAHASAN}

Hasil perhitungan korelasi dengan program SPSS diperoleh nilai sebagai berikut:

\section{Uji F}

Langkah langkah uji F:

\section{a. Hipotesis}

$\mathrm{H}_{\mathrm{o}}$ : Tidak terdapat pengaruh yang signifikan secara bersama sama antara hafalan al-Qur'an dan intensitas salat tahajud dengan nilai Qur'an Hadis

$\mathrm{H}_{1}$ : Terdapat pengaruh yang signifikan secara bersama sama antara hafalan al-Qur'an dan intensitas salat tahajud dengan nilai Qur'an Hadis

b. Nilai $F_{\text {tabel }}$

Dengan alpha $5 \%$ dan $\mathrm{df}_{1}=2, \mathrm{df}_{2}=38$ maka $\mathrm{F}_{\text {tabel }}$ sebesar 3,245

\section{c. Titik Kritis}

$\mathrm{H}_{\mathrm{o}}$ di tolak bila nilai $\mathrm{F}_{\text {hitung }}>\mathrm{F}_{\text {tabel }}$

d. Kesimpulan

\begin{tabular}{llccccc}
\multicolumn{7}{c}{ Tabel 1.1 Uji F } \\
\hline \multicolumn{7}{c}{ MNOVA } \\
\hline \multirow{2}{*}{ Model } & $\begin{array}{c}\text { Sum of } \\
\text { Squares }\end{array}$ & df & $\begin{array}{c}\text { Mean } \\
\text { Square }\end{array}$ & F & Sig. \\
\hline \multirow{2}{*}{$\begin{array}{l}\text { Regression } \\
1\end{array}$ Residual } & 20.806 & 2 & 10.403 & .389 & $.681^{\text {a }}$ \\
& Total & 962.938 & 36 & 26.748 & & \\
\hline
\end{tabular}

a. Predictors: (Constant), intensitas_tahajud, hafalan_quran

b. Dependent Variable: prestasi_quran_hadis

Berdasarkan olah data SPSS versi 16, diperoleh bahwa nilai $\mathrm{F}_{\text {hitung }}$ sebesar 0,389. Karena $\mathrm{F}_{\text {hitung }}(0,389)>\mathrm{F}_{\text {tabel }}(3,245)$, maka $\mathrm{H}_{\mathrm{o}}$ diterima. Jadi, tidak terdapat pengaruh yang signifikan secara bersama sama antara hafalan al-Qur'an dan intensitas salat tahajud terhadap nilai mata pelajaran Qur'an Hadis.

Faktor penyebab tidak terjadi pengaruh yang signifikan karena hafalan al-Qur'an dan intensitas salat tahajud tidak berpengaruh secara langsung terhadap 
prestasi belajar, melainkan melalui motivasi terlebih dahulu. Sehingga, melalui motivasi baik motivasi menghafal al-Qur'an maupun motivasi melaksanakan salat tahajud bisa menjadi penyebab prestasi belajar meningkat.

\section{Uji t}

Pengaruh hafalan al-Qur'an terhadap prestasi belajar mata pelajaran Qur'an Hadis secara parsial Langkah - langkah uji t:

\section{a. Hipotesis}

$\mathrm{H}_{\mathrm{o}}$ : Tidak terdapat pengaruh yang signifikan hafalan al-Qur'an terhadap nilai Qur'an Hadis

$\mathrm{H}_{1}$ : terdapat pengaruh yang signifikan hafalan al-Qur'an terhadap nilai Qur'an Hadis

b. Nilai $t_{\text {tabel }}$

Dengan alpha $5 \%$ dan $\mathrm{df}=\mathrm{n}-3=37$ maka nilai $t_{\text {tabel }}(2,5 \%, 37)$ sebesar 2.026

c. Titik Kritis

Ho ditolak bila | thitung | > ttabel

d. Kesimpulan

Tabel 1.2 Uji t

\begin{tabular}{|c|c|c|c|c|c|c|c|c|}
\hline \multicolumn{9}{|c|}{ Coefficients $^{a}$} \\
\hline & \multirow{2}{*}{ Model } & \multicolumn{2}{|c|}{$\begin{array}{l}\text { Unstandardized } \\
\text { Coefficients }\end{array}$} & \multirow{2}{*}{$\begin{array}{c}\begin{array}{c}\text { Standardized } \\
\text { Coefficients }\end{array} \\
\text { Beta }\end{array}$} & \multirow{2}{*}{$\mathrm{T}$} & \multirow{2}{*}{ Sig. } & \multicolumn{2}{|c|}{$\begin{array}{l}\text { Collinearity } \\
\text { Statistics }\end{array}$} \\
\hline & & B & $\begin{array}{c}\text { Std. } \\
\text { Error }\end{array}$ & & & & Tolerance & VIF \\
\hline \multirow{3}{*}{1} & (Constant) & 81.241 & 8.301 & & 9.787 & .000 & & \\
\hline & hafalan_quran & .036 & .196 & .038 & .182 & .856 & .637 & 1.571 \\
\hline & $\begin{array}{l}\text { intensitas_ } \\
\text { tahajud }\end{array}$ & .071 & .123 & .120 & .579 & .566 & .637 & 1.571 \\
\hline
\end{tabular}

Berdasar olah data statistik dengan SPSS versi 16, diperoleh $t_{\text {hitung }}$ sebesar 0,182 . Karena $t_{\text {hitung }}(0,182)<t_{\text {tabel }}(2.026)$, maka $\mathrm{H}_{\mathrm{o}}$ diterima. Jadi, tidak terdapat pengaruh yang signifikan antara hafalan al-Qur'an dengan nilai Qur'an Hadis.

Faktor penyebaab tidak terdapat pengaruh yang signifikan antara hafalan al-Qur'an terhadap prestasi belajar Qur'an hadis adalah karena bentuk soal ujian tidak hanya memfokuskan pada hafalan tetapi juga pada pemahaman makna dan arti kata dalam bahasa Arab.

3. Pengaruh intensitas salat tahajud terhadap prestasi belajar mata pelajaran Qur'an Hadis secara parsial

\section{Langkah -langkah uji t:}

a. Hipotesis

$\mathrm{H}_{\mathrm{o}}$ : Tidak terdapat pengaruh yang signifikan intensitas salat tahajud terhadap nilai Qur'an Hadis

$\mathrm{H}_{1}$ : terdapat pengaruh yang signifikan intensitas salat tahajud terhadap nilai Qur'an Hadis

b. Nilai $t_{\text {tabel }}$

Dengan alpha $5 \%$ dan df $=n-3=37$ maka nilai $t_{\text {tabel }}(2,5 \%, 37)$ sebesar 2.026

c. Titik Kritis

$\mathrm{H}_{\mathrm{o}}$ di tolak bila $\left|\mathrm{t}_{\text {hitung }}\right|>\mathrm{t}_{\text {tabel }}$

d. Kesimpulan 
Tabel 1.3 Uji t

\begin{tabular}{|c|c|c|c|c|c|c|c|c|}
\hline \multicolumn{9}{|c|}{ Coefficients $^{\mathrm{a}}$} \\
\hline & \multirow{2}{*}{ Model } & \multicolumn{2}{|c|}{$\begin{array}{l}\text { Unstandardized } \\
\text { Coefficients }\end{array}$} & \multirow{2}{*}{$\begin{array}{c}\begin{array}{c}\text { Standardized } \\
\text { Coefficients }\end{array} \\
\text { Beta }\end{array}$} & \multirow[t]{2}{*}{$\mathrm{T}$} & \multirow{2}{*}{ Sig. } & \multicolumn{2}{|c|}{ Collinearity Statistics } \\
\hline & & $\mathrm{B}$ & Std. Error & & & & Tolerance & VIF \\
\hline \multirow{3}{*}{1} & (Constant) & 81.241 & 8.301 & & 9.787 & .000 & & \\
\hline & hafalan_quran & .036 & .196 & .038 & .182 & .856 & .637 & 1.571 \\
\hline & intensitas_tahajud & .071 & .123 & .120 & .579 & .566 & .637 & 1.571 \\
\hline
\end{tabular}

a. Dependent Variable: prestasi_intensitas tahajud

Berdasar olah data statistik dengan SPSS versi 16, diperoleh $t_{\text {hitung }}$ sebesar 0,579. Karena $t_{\text {hitung }}(0,579)>t_{\text {tabel }}(2.026)$, maka $H_{\text {o }}$ diterima. Jadi,tidak terdapat pengaruh yang signifikan antara intensitas salat tahajud dengan nilai Qur'an Hadis.

Faktor penyebab tidak terdapat pengaruh yang signifikan antara intensitas salat tahajud terhadap prestasi belajar Qur'an hadis adalah karena kurang tekun santriwati dalam belajar terutama setelah melaksanakan salat tahajud.

\section{SIMPULAN}

Hasil perhitungan diperoleh nilai uji $\mathrm{F}_{\text {hitung }}$ sebesar 0,389 dan berdasar tabel diperoleh nilai $\mathrm{F}_{\text {tabel }}$ sebesar 3,245. Karena $\mathrm{F}_{\text {hitung }}<\mathrm{F}_{\text {tabel }}$ maka dapat disimpulkan bahwa tidak terdapat pengaruh yang signifikan secara bersama sama antara hafalan alQur'an dan intensitas salat tahajud terhadap nilai mata pelajaran Qur'an Hadis. Besarnya kontribusi nilai masing-masing variabel terhadap prestasi belajar dapat ditunjukkan oleh koefisien regresi yang secara berurutan adalah sebagai berikut: hafalan al-Qur'an 0,036 dan intensitas salat tahajud 0,071 Jadi, hafalan al-Qur'an memberi kontribusi nilai paling besar terhadap prestasi belajar Qur'an Hadis, baru disusul salat tahajud. Sementara itu, berdasarkan $R$ square, diperoleh bahwa 2,1 \% nilai Qur'an Hadis siswa ditentukan oleh hafalan al-Qur'an dan intensitas salat tahajud. Sedangkan, sisanya $97,9 \%$ ditentukan oleh faktor lain yang tidak diteliti dalam penelitian ini. Hasil dari penelitian di atas hanya mengenerasilisasi populasi kelas VIII MTs. Islam Ngruki dan MTs. PPMI Assalaam. Faktor penyebab tidak terjadi pengaruh yang signifikan karena hafalan al-Qur'an dan intensitas salat tahajud tidak berpengaruh secara langsung terhadap prestasi belajar, melainkan melalui motivasi terlebih dahulu. Sehingga, melalui motivasi baik motivasi menghafal al-Qur'an maupun motivasi melaksanakan salat tahajud bisa menjadi penyebab prestasi belajar meningkat.

Berdasar pada hasil penelitian, diperoleh nilai $t_{\text {hitung }}$ sebesar 0,182 dan nilai $t_{\text {tabel }} 2,026$. Karena $t_{\text {hitung }}<t_{\text {tabel, }}$ maka dapat disimpulkan bahwa pengaruh hafalan alQur'an terhadap prestasi belajar Qur'an Hadis secara parsial tidak signifikan. Faktor penyebab tidak terdapat pengaruh yang signifikan antara hafalan al-Qur'an terhadap prestasi belajar Qur'an hadis adalah karena bentuk soal ujian tidak hanya memfokuskan pada hafalan tetapi juga pada pemahaman makna dan arti kata dalam bahasa Arab.

Berdasarkan hasil penelitian, diperoleh nilai $t_{\text {hitung }}$ sebesar 0,579 dan nilai $t_{\text {tabel }} 2,026$. Karena $t_{\text {hitung }}<t_{\text {tabel, }}$ maka dapat disimpulkan bahwa tidak terdapat pengaruh yang signifikan secara parsial intensitas salat tahajud terhadap prestasi belajar Qur'an Hadis. Faktor penyebab tidak terdapat pengaruh yang signifikan antara intensitas salat tahajud terhadap prestasi belajar Qur'an hadis adalah karena kurang tekun santriwati dalam belajar terutama setelah melaksanakan salat tahajud.

\section{DAFTAR PUSTAKA}

Interview dengan ustadzah penanggung jawab tahfizh Pondok Pesantren Islam Al-Mukmin dan Assalaam Sukoharjo pada tanggal 7 Agustus 2014 
PROFETIKA, Jurnal Studi Islam, Vol. 18, No. 1, Juni 2017: 48-54

Jahangir, Nazia Nawaz dan Syeda Farhana. 2015. Effects of Memorizing Quran by Heart (Hifz) on Later Academic Achievement. Amerika: American research institute for policy development.

Maulida Nisful Laila, "Korelasi Antara Pelaksanaan Salat Tahajud dan Prestasi belajar Aqidah Akhlak Siswa di MAN Denanyar Jombang", Skripsi, (Surabaya: Universitas Islam Negeri Sunan Ampel, 2014).

Munir, Ferri Andika Rosadi dan Muhammad. 2014. "Pengaruh Kemampuan Menghafal Al-Qur'an dan Motivasi Belajar terhadap Prestasi Belajar Siswa Ekstrakurikuler Elektronika SMP Islam Terpadu Abu Bakar Yogyakarta". Yogyakarta: Fakultas Teknik Universitas Negeri Yogyakarta. 